\title{
Invasive pneumococcal disease rates linked to meteorological factors and respiratory virus circulation (Catalonia, 2006-2012)
}

\author{
Pilar Ciruela ${ }^{1 *}$, Sonia Broner ${ }^{1}$, Conchita Izquierdo', Sergi Hernández', Carmen Muñoz-Almagro², Roman Pallarés ${ }^{3,4}$, \\ Mireia Jané ${ }^{1}$, Angela Domínguez ${ }^{4,5}$ and on behalf of the Working Group of Invasive Pneumococcal Disease of \\ Catalonia
}

\begin{abstract}
Background: To study the impact of meteorological data and respiratory viral infections on invasive pneumococcal disease (IPD) rates.

Methods: We analysed all notifications of IPD and respiratory viral infections to the Microbiological Reporting System of Catalonia (2006-2012). Correlations between rates of IPD and viral infections (influenza virus, respiratory syncytial virus [RSV] and adenovirus), and meteorological variables (temperature, humidity, hours of sunshine, wind speed and number of days with rainfall) were assessed using Spearman's correlation coefficient and negative binomial regression models.

Results: We found significant correlations between monthly rates of IPD and monthly rates of all respiratory viruses and meteorological factors.

However, after multiple regression analysis, associations remained between IPD rates and influenza rates and reductions in temperature in the total population, and between IPD rates and adenovirus rates in children aged $<5$ years.

When models were repeated for the total population using data from the preceding month, IPD rates increased when RSV was circulating and when the temperature was lower. In children aged $<5$ years, RSV circulation was associated with increased IPD rates.
\end{abstract}

Conclusions: IPD rates were linked to increased activity of some respiratory viruses and reductions in temperature. Preventive measures, including influenza vaccination, may help reduce IPD.

Keywords: Streptococcus pneumoniae, IPD, Respiratory viruses, Influenza, Meteorological variables

\section{Background}

Invasive pneumococcal disease (IPD) remains a serious public health problem. The epidemiology of the disease shows seasonal patterns with a higher incidence in winter months $[1,2]$ related to increased respiratory virus activity [3-5].

Host, sociodemographic, and climatic factors, and previous respiratory viral infections $[2,6-8]$ have been associated with increases in IPD.

Viral respiratory infections, particularly those caused by the influenza virus and respiratory syncytial virus

\footnotetext{
*Correspondence: pilar.ciruela@gencat.cat

${ }^{1}$ Agència de Salut Pública de Catalunya. Generalitat de Catalunya, Roc

Boronat 81-95, 08005 Barcelona, Spain

Full list of author information is available at the end of the article
}

(RSV) enhance the incidence of IPD using different mechanisms [9]. Viral respiratory infections damage respiratory epithelial cells [10] and predispose to secondary bacterial infections by promoting bacterial adhesion to the respiratory epithelium $[9,11]$. Moreover, viral infection may reduce cell clearance of Streptococcus pneumoniae in previously-colonized respiratory cells [12], easing the spread by aspiration or adhesion to sterile areas.

In Catalonia, Spain, the incidence of viral respiratory infection [5] and IPD [13] is high, although a reduction in IPD rates has been detected in recent years, probably influenced by the administration of pneumococcal vaccines. The 23-valent pneumococcal polysaccharide vaccine (PPV23) and the influenza vaccine are recommended for 
persons with high-risk medical conditions and for all persons aged $>60$ years [14]. The 7-valent pneumococcal conjugate vaccine (PCV7) and 13-valent pneumococcal conjugate vaccine (PCV13) are not currently included in the routine vaccination schedule of Catalonia, and are only indicated and offered for free in children aged $<5$ years with risk factors [14]. Estimated vaccine coverage are around $50 \%$ in adults for the PPV23 [15] and 55.1, 1.4 and $12.5 \%$ for the PCV13, PCV10 and PCV7, respectively, in children [16].

Several authors have studied the association between IPD and respiratory virus infection and meteorological variables and although most found an association between IPD and influenza virus and RSV [2, 17-19], the results differ substantially according to the statistical methods used $[8,20]$.

The objective of this study was to investigate the correlation between fluctuations in respiratory virus activity and meteorological data with IPD rates in Catalonia over a 7 -year period.

\section{Methods \\ Setting}

Catalonia is a region in the northeast of Spain located at latitude $41.6^{\circ} \mathrm{N}$. It has a temperate maritime climate with winters during December-March. The total population in 2012 was 7,570,908, of whom 423,308 were aged $<5$ years, 5,860,079 aged 5-64 years, and 1,287,521 aged $\geq 65$ years [21].

\section{Study design}

An ecological study was carried out in Catalonia from January 2006 to December 2012. All prospective notifications of IPD and adenovirus, influenza virus, and RSV infections reported to the Microbiological Reporting System of Catalonia (MRSC) coordinated by the Public Health Agency of Catalonia were analyzed.

The MRSC has been a sentinel enhanced surveillance system [22] since 1995 and involves 50 health care centers representing over $82.2 \%$ of hospital beds in public hospitals in Catalonia ( 45 public hospitals acute out of a total of 67) [23]. Microbiologists report acute cases of infectious diseases, with sociodemographic and clinical information, case by case or weekly.

\section{Variables}

IPD was defined as S. pneumoniae isolation or detection of nucleic acids by polymerase chain reaction (PCR) or antigen detection in normally sterile body fluids. Respiratory virus infections were diagnosed by culture, PCR, or detection of antigen from clinical respiratory specimens.

The data collected included the number of cases of IPD (dependent variable) and respiratory virus infections (independent variable) per month in the study period. To calculate incidence rates, the population for each year was obtained from the Statistical Institute of Catalonia [21].

Meteorological data, including temperature, humidity, hours of sunshine, wind speed and number of days with rainfall were obtained from the Spanish National Statistics Institute and the Meteorological Service of Catalonia [24, 25]. Data were obtained from the four provincial meteorological stations in Catalonia (Barcelona, Girona, Lleida and Tarragona). Temperature $\left({ }^{\circ} \mathrm{C}\right)$, hours of sunshine, wind speed $(\mathrm{km} / \mathrm{h})$, relative humidity (\%) and number of days with rainfall was recorded each month (see Additional file 1).

\section{Statistical methods}

Age-specific incidence rate ratios (IRR) with $95 \%$ confidence intervals $(\mathrm{CI})$ were calculated for IPD, and influenza virus, RSV and adenovirus infections.

The relationships between monthly rates of IPD and rates of respiratory virus infection and monthly means of meteorological variables were assessed using Spearman's rank correlation coefficient. The analysis was repeated with data on viral infections and meteorological variables from the previous month (1-month lag) to analyze their influence on the rates of IPD [8].

Regression analysis was used to further assess the relationship between monthly rates of IPD, viral infections and meteorological variables. Only variables that were significant in the correlation analysis were included. Negative binomial regression models were constructed for the total population and for the $<5$ years, $5-64$ years, and $\geq 65$ years age groups.

In all models, the monthly rate of IPD was the outcome variable. The explanatory variables (all binary) used were the monthly rate of viral infections, mean average monthly temperature $>17{ }^{\circ} \mathrm{C}$, mean average monthly hours of sunshine $>7 \mathrm{~h}$, mean average monthly wind speed $>11 \mathrm{~km} / \mathrm{h}$, mean average monthly humidity $>64 \%$, and mean average monthly number of days with rainfall $>7$ days. Viruses were considered as circulating during a given month when the viral infection was reported from at least two people during that month [8]. Correlations with meteorological variables were measured. The analyses were performed using the Statistical Package for Social Sciences (SPSS 19.0 for Windows) and R 2.13.0 (R Development Core Team 2014).

\section{Results}

\section{Invasive pneumococcal disease}

During the study period there were 8044 episodes of IPD and the incidence rate (IR) was 15.5 per 100,000 personsyear. Most cases were diagnosed by culture $(94.7 \%)$, and 4664 ( $58 \%$ ) were male. The median age of cases was 55 (range $0-100$ years) and the highest incidence rate was in 
Table 1 Incidence rates of invasive pneumococcal disease and respiratory virus infection by age group. Catalonia, 2006-2012

\begin{tabular}{|c|c|c|c|c|c|c|c|c|}
\hline & \multicolumn{2}{|c|}{ All ages } & \multicolumn{2}{|c|}{$<5$ years } & \multicolumn{2}{|c|}{ 5-64 years } & \multicolumn{2}{|c|}{$\geq 65$ years } \\
\hline & $\bar{n}$ & Incidence rate ${ }^{a}$ & $\bar{n}$ & Incidence rate ${ }^{a}$ & $\bar{n}$ & Incidence rate ${ }^{\mathrm{a}}$ & $\bar{n}$ & Incidence rate ${ }^{a}$ \\
\hline IPD & 8044 & $15.5(15.2-15.9)$ & 1430 & $50.0(47.5-52.7)$ & 3528 & $8.7(8.5-9.0)$ & 3020 & $35.3(34.0-36.5)$ \\
\hline Influenza & 6845 & $13.2(12.9-13.5)$ & 2588 & $90.5(87.1-94.1)$ & 3710 & $9.2(8.9-9.5)$ & 472 & $5.5(5.0-6.0)$ \\
\hline RSV & 9507 & $18.4(18.0-18.7)$ & 9079 & $317.5(311.2-324.1)$ & 283 & $0.7(0.6-0.8)$ & 81 & $1.0(0.8-1.2)$ \\
\hline Adenovirus & 1211 & $2.3(2.2-2.5)$ & 991 & 34.7 (32.5-36.9) & 181 & $0.5(0.4-0.5)$ & 32 & $0.4(0.3-0.5)$ \\
\hline
\end{tabular}

Abbreviations: IPD invasive pneumococcal disease, $R S V$ respiratory syncytial virus

${ }^{a}$ per 100,000 persons-year

children aged $<5$ years (IR: 50 per 100,000 persons-year) (Table 1). Pneumonia was the most frequent clinical presentation with 5945 cases (73.9\%), of which pneumonia with empyema represented $11.7 \%$ (693 cases), followed by non-focal bacteremia (1347 cases; $16.7 \%$ ), and meningitis (606 cases; $7.5 \%$ ). Other clinical presentations of IPD represented $1.8 \%$ (146) cases, including peritonitis (86 cases; $58.9 \%$ ), arthritis (43 cases; $29.5 \%$ ), cellulitis (6 cases; $4.1 \%$ ), cholecystitis (3 cases, $2.1 \%$ ), pericarditis (3 cases, $2.1 \%)$, endocarditis (2, $1.4 \%)$, mastoiditis $(2,1.4 \%)$ and endophthalmitis (1, $0.7 \%)$. A total of $74.3 \%$ of strains (5973) were serotyped: the most frequent serotypes were 1 (931; $15.6 \%), 19 \mathrm{~A}(596 ; 10.0 \%), 7$ F (528; $8.8 \%), 3$ (523; $8.8 \%)$ and 14 (379; $6.3 \%)$.

\section{Respiratory virus infection}

During the study period, 17,563 respiratory virus infections were reported. The highest incidence rate was in children aged $<5$ years (Table 1). Of the 9507 cases of RSV (IR: 18.4 per 100,000 persons-year), 9,079 (IR: 317.5 per 100,000 persons-year) occurred in children aged $<5$ years. There were 6,845 cases of influenza virus infection (IR: 13.2 per 100,000 persons-year) of which 2,588 were in children aged <5 years (IR: 90.5 per 100,000 persons-year) and almost $90 \%$ were influenza A $(5,922)$. Of the 1,211 cases of adenovirus infection (IR: 2.3 per 100,000 persons-year) 991 cases occurred in children aged $<5$ years (IR: 34.7 per 100,000 persons-year).

\section{Seasonal distribution}

IPD showed a seasonal pattern, with the highest incidence in the winter months (November to March), coinciding with the peak of influenza activity (January to March). RSV infections started to rise 4 to 6 weeks before the peaks of IPD and influenza activity. In 2009, there was a sharp increase in influenza virus infections due to the global H1N1 influenza pandemic 4 weeks before the increase in RSV incidence (Fig. 1). The incidence of adenovirus was low, with an increase in February and March.

\section{Meteorological factors}

During the study period the mean and median temperature were $16.5^{\circ} \mathrm{C}$ and $16.7{ }^{\circ} \mathrm{C}$ (standard deviation: $6.4{ }^{\circ} \mathrm{C}$; range: $6.8^{\circ} \mathrm{C}-27.6{ }^{\circ} \mathrm{C}$ ), the mean and median hours of sunshine were $6.9 \mathrm{~h}$ (standard deviation: $2.0 \mathrm{~h}$; range: $3.3 \mathrm{~h}-10.7 \mathrm{~h}$ ), the mean and median wind speed were $10.6 \mathrm{Km} / \mathrm{h}$ and $10.8 \mathrm{Km} / \mathrm{h}$ (standard deviation: $1.4 \mathrm{Km} / \mathrm{h}$; range: $7.3 \mathrm{Km} /$ h-14.0 Km/h), the mean and median relative humidity were $63.3 \%$ and $62.4 \%$ (standard deviation: $6.8 \%$; range: $49.8 \%-80.56 \%)$ and the mean and median number of days with rainfall were 7 days and 6 days (standard deviation: 3 days; range: 2 days-15 days).

Figure 2 shows the monthly variations in meteorological variables for the study period compared with the monthly rate of IPD. There was an increase in IPD when the temperature, hours of sunshine and wind speed were lower and humidity and number of days with rainfall was higher.

\section{Correlation between IPD, respiratory virus infection, and meteorological factors}

There was a correlation between monthly detection rates of all respiratory viral infections and meteorological variables with rates of IPD (Table 2). These results remained when the analysis was repeated with a 1-month lag. The correlation between RSV and influenza virus and IPD remained after stratifying the data by all age groups, in the concurrent month and with a 1-month lag. Adenovirus infections correlated with IPD in the $<5$ years age group (in the concurrent month and with a 1-month lag) and in the 5-64 years age group only in the concurrent month. All meteorological variables correlated with IPD in the concurrent month and with a 1-month lag.

\section{Regression models}

The results of the bivariate regression analysis presented in Table 3 showed significant associations between adenovirus, influenza virus and RSV and IPD. After stratifying by age groups, the association remained significant in all age groups for influenza virus and RSV. Adenovirus was only significant in children aged $<5$ years. 


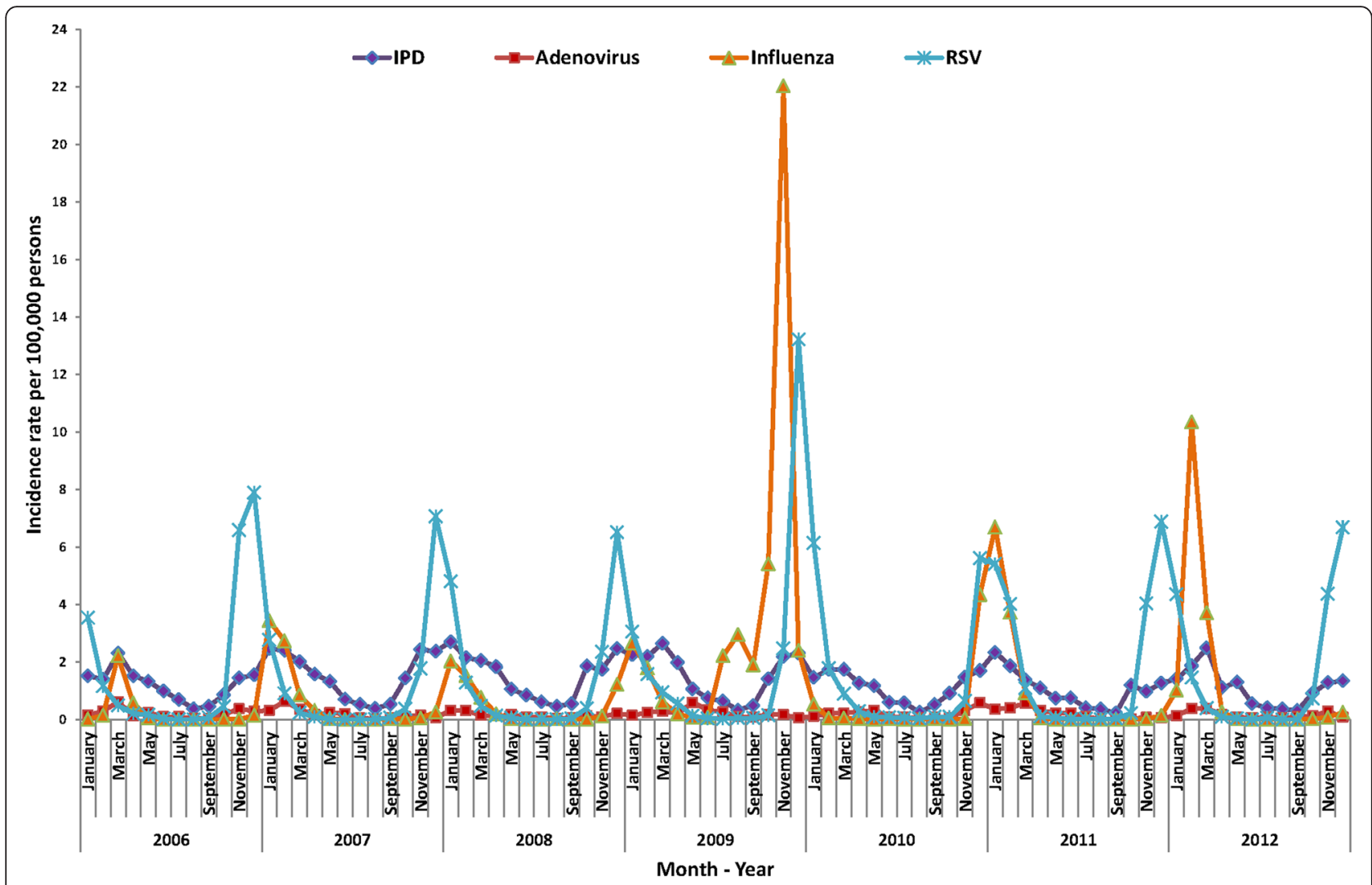

Fig. 1 Monthly rates of invasive pneumococcal disease and respiratory virus detection over the 7-year study period. Catalonia, 2006-2012

The same results were obtained in the total population when the models were repeated using a 1-month lag. RSV was significant in all age groups and influenza virus in children aged $<5$ years and persons aged 5-64 years. Adenovirus was not significant in any age group.

The mean monthly temperature correlated closely with mean monthly hours of sunshine $(r=0.85, p<0.001)$, mean monthly wind speed $(r=0.44, p<0.001)$, mean monthly relative humidity $(r=-0.64, p<0.001)$ and mean monthly number of days with rainfall $(r=-0.34, p=0.001)$ and therefore we only included temperature in the regression models. In addition, temperature had shown the closest correlation with IPD.

The results of the multivariate regression analyses for all age groups are presented in Table 4. Accounting for the effects of independent variables in all age groups, rates of IPD increased during the circulation of the influenza virus (IRR: 1.26, $95 \%$ CI: 1.03-1.54) and decreased when the monthly temperature was $>17^{\circ} \mathrm{C}$ (IRR: 0.47, $95 \% \mathrm{CI}: 0.39-0.57)$. When the models were repeated using data from the preceding month, rates of IPD increased when the RSV was circulating (IRR: 1.81, $95 \%$ CI: 1.36-2.41) and decreased when the monthly temperature was $>17{ }^{\circ} \mathrm{C}$ (IRR: 0.56, $95 \%$ CI: 0.45-0.70).
The increase in the rate of IPD was significant during the adenovirus circulation season in children aged $<5$ years (IRR: $2.47,95 \%$ CI: $1.38-4.53$ ). Rates of IPD decreased during months with a monthly temperature $>17{ }^{\circ} \mathrm{C}$ in all age groups $(<5$ years: IRR: $0.58,95 \% \mathrm{CI}$ : 0.44-0.77; 5-64 years: IRR: 0.47, $95 \%$ CI: $0.37-0.59$ and $\geq 65$ years: IRR: $0.37,95 \%$ CI: $0.31-0.44)$. When the models were repeated using a 1-month lag, rates of IPD increased during RSV circulation (IRR: 2.57, 95 \% CI: $1.78-3.71)$, in the $<5$ years age group. Rates of IPD decreased when the monthly temperature was $>17{ }^{\circ} \mathrm{C}$ in the 5-64 years age group (IRR: $0.54,95 \%$ CI: 0.41-0.70) and $\geq 65$ years age group (IRR: $0.42,95 \%$ CI: $0.34-0.51$ ).

The results of the models were similar when the analyses were repeated excluding data on influenza virus infection during the 2009 season, which appeared to be outliers due to the influenza A H1N1 pandemic.

\section{Discussion}

The results of this study showed a temporal association between high IPD rates and increased respiratory viral activity according to age groups and an association between increases in IPD incidence and reductions in temperature. 


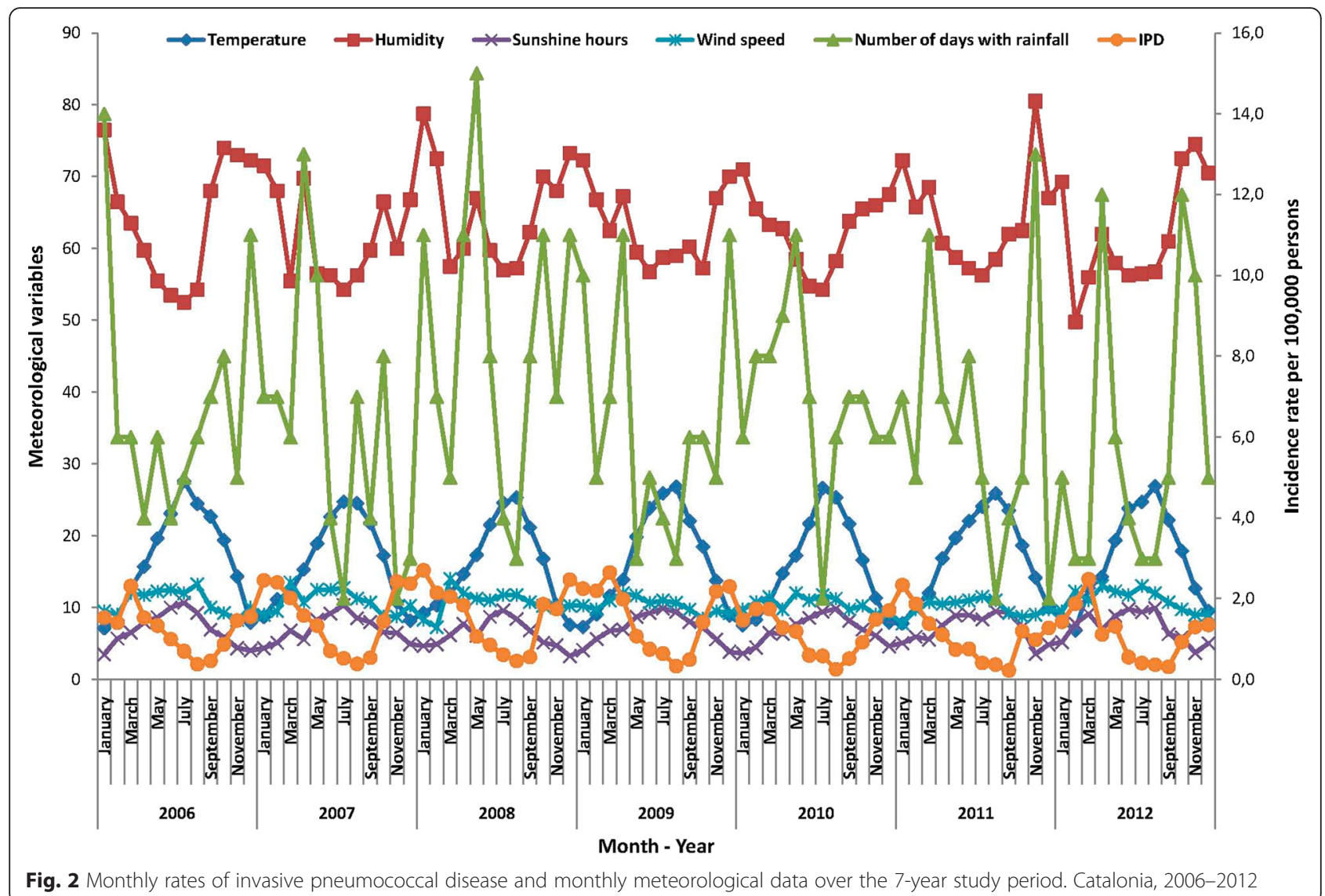

Table 2 Correlation of monthly rates of invasive pneumococcal disease with rates of respiratory virus infection in concurrent and preceding month. Catalonia, 2006-2012

\begin{tabular}{|c|c|c|c|c|c|c|c|c|}
\hline \multirow[t]{2}{*}{ Variable } & \multicolumn{2}{|l|}{ All ages } & \multicolumn{2}{|l|}{$<5$ years } & \multicolumn{2}{|c|}{$5-64$ years } & \multicolumn{2}{|l|}{$\geq 65$ years } \\
\hline & $\begin{array}{l}\text { No lag a } \\
\text { (p-value) }\end{array}$ & $\begin{array}{l}\text { 1-month lag }{ }^{b} \\
\text { ( } p \text {-value) }\end{array}$ & $\begin{array}{l}\text { No laga } \\
\text { (p-value) }\end{array}$ & $\begin{array}{l}\text { 1-month lag }{ }^{b} \\
\text { ( } p \text {-value) }\end{array}$ & $\begin{array}{l}\text { No laga } \\
\text { ( } p \text {-value) }\end{array}$ & $\begin{array}{l}\text { 1-month lagb } \\
\text { ( } p \text {-value) }\end{array}$ & $\begin{array}{l}\text { No lag } \\
\text { (p-value) }\end{array}$ & $\begin{array}{l}\text { 1-month lag } \\
\text { ( } p \text {-value) }\end{array}$ \\
\hline Influenza & $\begin{array}{l}0.71 \\
(<0.001)\end{array}$ & $\begin{array}{l}0.64 \\
(<0.001)\end{array}$ & $\begin{array}{l}0.60 \\
(<0.001)\end{array}$ & $\begin{array}{l}0.57 \\
(<0.001)\end{array}$ & $\begin{array}{l}0.65 \\
(<0.001)\end{array}$ & $\begin{array}{l}0.57 \\
(<0.001)\end{array}$ & $\begin{array}{l}0.41 \\
(<0.001)\end{array}$ & $\begin{array}{l}0.36 \\
(0.001)\end{array}$ \\
\hline RSV & $\begin{array}{l}0.77 \\
(<0.001)\end{array}$ & $\begin{array}{l}0.80 \\
(<0.001)\end{array}$ & $\begin{array}{l}0.63 \\
(<0.001)\end{array}$ & $\begin{array}{l}0.61 \\
(<0.001)\end{array}$ & $\begin{array}{l}0.50 \\
(<0.001)\end{array}$ & $\begin{array}{l}0.44 \\
(<0.001)\end{array}$ & $\begin{array}{l}0.38 \\
(<0.001)\end{array}$ & $\begin{array}{l}0.38 \\
(<0.001)\end{array}$ \\
\hline Adenovirus & $\begin{array}{l}0.61 \\
(<0.001)\end{array}$ & $\begin{array}{l}0.39 \\
(<0.001)\end{array}$ & $\begin{array}{l}0.55 \\
(<0.001)\end{array}$ & $\begin{array}{l}0.32 \\
(0.003)\end{array}$ & $\begin{array}{l}0.23 \\
(0.040)\end{array}$ & $\begin{array}{l}0.17 \\
(0.137)\end{array}$ & $\begin{array}{l}0.09 \\
(0.396)\end{array}$ & $\begin{array}{l}-0.05 \\
(0.663)\end{array}$ \\
\hline Temperature & $\begin{array}{l}-0.85 \\
(<0.001)\end{array}$ & $\begin{array}{l}-0.84 \\
(<0.001)\end{array}$ & $\begin{array}{l}-0.65 \\
(<0.001)\end{array}$ & $\begin{array}{l}-0.64 \\
(<0.001)\end{array}$ & $\begin{array}{l}-0.82 \\
(<0.001)\end{array}$ & $\begin{array}{l}-0.82 \\
(<0.001)\end{array}$ & $\begin{array}{l}-0.87 \\
(<0.001)\end{array}$ & $\begin{array}{l}-0.86 \\
(<0.001)\end{array}$ \\
\hline Humidity & $\begin{array}{l}0.48 \\
(<0.001)\end{array}$ & $\begin{array}{l}0.62 \\
(<0.001)\end{array}$ & $\begin{array}{l}0.39 \\
(<0.001)\end{array}$ & $\begin{array}{l}0.56 \\
(<0.001)\end{array}$ & $\begin{array}{l}0.46 \\
(<0.001)\end{array}$ & $\begin{array}{l}0.60 \\
(<0.001)\end{array}$ & $\begin{array}{l}0.48 \\
(<0.001)\end{array}$ & $\begin{array}{l}0.63 \\
(<0.001)\end{array}$ \\
\hline Sunshine hours & $\begin{array}{l}-0.67 \\
(<0.001)\end{array}$ & $\begin{array}{l}-0.79 \\
(<0.001)\end{array}$ & $\begin{array}{l}-0.53 \\
(<0.001)\end{array}$ & $\begin{array}{l}-0.62 \\
(<0.001)\end{array}$ & $\begin{array}{l}-0.65 \\
(<0.001)\end{array}$ & $\begin{array}{l}-0.76 \\
(<0.001)\end{array}$ & $\begin{array}{l}-0.67 \\
(<0.001)\end{array}$ & $\begin{array}{l}-0.81 \\
(<0.001)\end{array}$ \\
\hline Wind speed & $\begin{array}{l}-0.31 \\
(0.005)\end{array}$ & $\begin{array}{l}-0.58 \\
(<0.001)\end{array}$ & $\begin{array}{l}-0.29 \\
(0.008)\end{array}$ & $\begin{array}{l}-0.54 \\
(<0.001)\end{array}$ & $\begin{array}{l}-0.30 \\
(0.006)\end{array}$ & $\begin{array}{l}-0.57 \\
(<0.001)\end{array}$ & $\begin{array}{l}-0.28 \\
(0.010)\end{array}$ & $\begin{array}{l}-0.54 \\
(<0.001)\end{array}$ \\
\hline Days with rainfall & $\begin{array}{l}0.29 \\
(0.008)\end{array}$ & $\begin{array}{l}0.25 \\
(0.021)\end{array}$ & $\begin{array}{l}0.25 \\
(0.024)\end{array}$ & $\begin{array}{l}0.24 \\
(0.031)\end{array}$ & $\begin{array}{l}0.30 \\
(0.006)\end{array}$ & $\begin{array}{l}0.25 \\
(0.022)\end{array}$ & $\begin{array}{l}0.27 \\
(0.013)\end{array}$ & $\begin{array}{l}0.27 \\
(0.013)\end{array}$ \\
\hline
\end{tabular}

Abbreviations: RSV respiratory syncytial virus

Note: Numbers are Spearman's rank correlation coefficients

${ }^{a}$ Concurrent month

bPreceding month 
Table 3 Results of bivariate regression analysis between invasive pneumococcal disease rates and respiratory virus infection rates and temperature for concurrent months and 1-month lag. Catalonia, 2006-2012

\begin{tabular}{|c|c|c|c|c|c|c|c|c|}
\hline \multirow[t]{3}{*}{ Variable } & \multicolumn{2}{|l|}{ All ages } & \multicolumn{2}{|l|}{$<5$ years } & \multicolumn{2}{|l|}{ 5-64 years } & \multicolumn{2}{|l|}{$\geq 65$ years } \\
\hline & No $\operatorname{lag}^{a}$ & 1-month lag & No $\operatorname{lag}^{a}$ & 1-month lag & No $\operatorname{lag}^{a}$ & 1-month lag & No $\operatorname{lag}^{a}$ & 1-month lag ${ }^{\mathrm{b}}$ \\
\hline & IRR (95 \% CI) & IRR (95 \% CI) & IRR (95 \% CI) & IRR (95 \% CI) & IRR (95 \% CI) & IRR (95 \% CI) & IRR (95 \% CI) & IRR (95 \% CI) \\
\hline Influenza & $2.13(1.71-2.63)$ & $1.85(1.46-2.33)$ & $1.86(1.44-2.39)$ & $1.59(1.22-2.07)$ & $2.08(1.69-2.57)$ & $1.84(1.47-2.31)$ & $1.37(1.03-1.83)$ & $1.29(0.96-1.74)$ \\
\hline RSV & $2.41(1.78-3.22)$ & $2.94(2.21-3.87)$ & $2.49(1.76-3.48)$ & $3.22(2.31-4.47)$ & $1.82(1.45-2.29)$ & $1.76(1.40-2.24)$ & $1.59(1.13-2.30)$ & $1.66(1.19-2.40)$ \\
\hline Adenovirus & $3.47(1.39-7.30)$ & $3.44(1.37-7.25)$ & $4.43(2.25-8.61)$ & $1.62(0.85-2.89)$ & $1.14(0.88-1.47)$ & $1.11(0.86-1.44)$ & $1.35(0.85-2.30)$ & $1.19(0.74-2.03)$ \\
\hline $\begin{array}{l}\text { Temperature } \\
>17^{\circ} \mathrm{C}\end{array}$ & $0.39(0.35-0.46)$ & $0.45(0.37-0.55)$ & $0.44(0.35-0.55)$ & $0.55(0.43-0.71)$ & $0.39(0.33-0.46)$ & $0.45(0.37-0.55)$ & $0.37(0.32-0.44)$ & $0.41(0.34-0.49)$ \\
\hline
\end{tabular}

Abbreviations: IRR Incidence rate ratio, CI Confidence interval, $R S V$ respiratory syncytial virus

${ }^{a}$ Concurrent month

${ }^{b}$ Preceding month

In the univariate model, there were associations between IPD and all respiratory virus infections studied (influenza virus, RSV, and adenovirus), in the whole population and in most age groups in the concurrent month and in the previous month. Kim et al. [2] found similar results in adults but not in children, showing an association between IPD and respiratory virus infections (influenza, RSV and adenovirus) in children that was weaker and less immediate than in adults, with a 4-week lag period. The study by Ampofo et al. [18] in children aged $<18$ years found an association between IPD and influenza and RSV infection in all periods studied (concurrent month and four previous weeks) although, unlike our study, they only found association between IPD and adenovirus in the two previous weeks between IPD and adenovirus. Other authors have found an association between IPD and RSV but no association between IPD and adenovirus [26, 27] and influenza infection [26-28] in children.

In the multivariate model, a high incidence of IPD was associated with an increase in influenza virus infection in the concurrent month and an increase in RSV infection in the previous month in the total population. In children aged $<5$ years there was an association between IPD and adenovirus in the concurrent month and with RSV in the previous month. No association was found in other age groups. A reduction in temperature was associated with high IPD incidence in all age groups.

The association between IPD and influenza virus infection in adults has been described by various authors using different statistical models. A multivariate New Zealand study by Murdoch et al. [8] that included respiratory virus infections (influenza, RSV, adenovirus and parainfluenza virus) and meteorological factors found an association between IPD and influenza virus infection in the whole population and in adults aged $\geq 65$ years. A UK study by Nicoli et al. [20] found similar results in a regression model including only influenza virus infection and RSV when they adjusted by temperature. In contrast, our results showed an association between IPD and influenza virus infection in the whole population but not in older age groups. This was probably due to the small number of influenza virus infection cases reported in adults aged $\geq 65$ years. The increase in reported influenza infections from 2009 onwards, after the H1N1 pandemic, was probably due to increased physician awareness of the disease and increased reporting, leading to more confirmed diagnoses.

The association between IPD and RSV found in our study has, with some differences, been described by Nicoli et al. [20], who found an association in all age groups in the concurrent month and the previous month: our

Table 4 Results of multivariate regression analysis of the relationship between invasive pneumococcal disease rates and respiratory virus infection rates and temperature for concurrent months and 1-month lag. Catalonia, 2006-2012

\begin{tabular}{|c|c|c|c|c|c|c|c|c|}
\hline \multirow[t]{3}{*}{ Variable } & \multicolumn{2}{|l|}{ All ages } & \multicolumn{2}{|l|}{$<5$ years } & \multicolumn{2}{|l|}{ 5-64 years } & \multicolumn{2}{|l|}{$\geq 65$ years } \\
\hline & No lag ${ }^{a}$ & 1-month lag ${ }^{\mathrm{b}}$ & No lag ${ }^{a}$ & 1-month lag ${ }^{\mathrm{b}}$ & No lag ${ }^{a}$ & 1-month lag ${ }^{\mathrm{b}}$ & No $\operatorname{lag}^{a}$ & 1-month lag ${ }^{\mathrm{b}}$ \\
\hline & IRR (95 \% Cl) & IRR (95 \% Cl) & IRR (95 \% Cl) & IRR $(95 \%$ Cl) & IRR (95 \% Cl) & IRR $(95 \%$ Cl) & IRR (95 \% Cl) & IRR (95 \% Cl) \\
\hline Influenza & $1.26(1.03-1.54)$ & $1.09(0.87-1.36)$ & $1.16(0.90-1.50)$ & $1.06(0.80-1.42)$ & $1.22(0.98-1.53)$ & $1.20(0.89-1.34)$ & $0.92(0.76-1.14)$ & $0.94(0.74-1.21)$ \\
\hline RSV & $1.15(0.89-1.48)$ & $1.81(1.36-2.41)$ & $1.41(1.00-1.97)$ & $2.57(1.78-3.71)$ & $1.12(0.91-1.37)$ & $1.15(0.90-1.48)$ & $1.04(0.81-1.33)$ & $1.13(0.85-1.52)$ \\
\hline Adenovirus & $1.58(0.88-2.74)$ & $1.32(0.68-2.42)$ & $2.47(1.38-4.53)$ & $1.00(0.59-1.68)$ & $1.14(0.96-1.35)$ & $1.10(0.90-1.34)$ & $1.32(0.96-1.83)$ & $1.19(0.82-1.77)$ \\
\hline $\begin{array}{l}\text { Temperature } \\
>17^{\circ} \mathrm{C}\end{array}$ & $0.47(0.39-0.57)$ & $0.56(0.45-0.70)$ & $0.58(0.44-0.77)$ & $0.76(0.56-1.02)$ & $0.47(0.37-0.59)$ & $0.54(0.41-0.70)$ & $0.37(0.31-0.44)$ & $0.42(0.34-0.51)$ \\
\hline
\end{tabular}

Abbreviations: IRR Incidence rate ratio, $\mathrm{Cl}$ Confidence interval $R S V$ respiratory syncytial virus

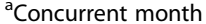

${ }^{\mathrm{b}}$ Preceding month 
results show only an association in the total population and in children aged $<5$ years, and only in the previous month. Other studies found no association in any age group or at any time [8].

Few multivariate studies have included adenovirus in the analysis. Murdoch et al. [8] found an association between IPD and adenovirus infection in the whole population and in adults aged $\geq 65$ years in the previous month. In contrast, we observed an association in children aged $<5$ years in the concurrent month but not in other age groups. The difference may be explained, in part, by the small number of cases in these age groups.

As stated previously, the meteorological variables studied (hours of sunshine, wind speed, relative humidity and number of days with rainfall) were collinear with temperature and therefore we only included temperature in the regression models. The results showed that a lower temperature was associated with IPD rates in all age groups in the concurrent month and in the previous month, except in children aged $<5$ years, where it was only significant in the concurrent month. A decrease in temperature might be linked with IPD because it could increase host susceptibility to pneumococcal infection [20,28].

Other studies have included other meteorological variables. Kim et al. [2] found an association between IPD and temperature in all age groups but an association between IPD and air pollution $\left(\mathrm{SO}^{2}\right)$ only in adults. Murdoch et al. [8] included pollution, rainfall, humidity, hours of sunshine and temperature in a regression model and found pollution was associated with IPD in the 5-65 years age group in the concurrent month and in adults aged $>65$ years in the previous month, and humidity was associated with IPD in children aged $<5$ years in the preceding month. They found no association between reduced temperatures and IPD in any age group, in contrast to our results and those of Nicoli et al. [20].

The main strength of this study is that the data came from the MRSC and were confirmed and completed by using other sources such as the Spanish and Catalan IPD reference centers. The same source was used for all microorganisms studied, and hospital and community cases were included. The sample size of the study is another strength.

The study has some limitations. We did not include other viruses (rhinovirus or metapneumovirus) because they were not reported to the MRSC. The parainfluenza virus was also excluded because cases were not reported regularly by hospitals and this could have biased the results. Although only a small number of influenza virus infections were reported in adults aged $\geq 65$ years, we detected an increase after 2008, probably due to more reports and diagnoses after the influenza pandemic. Likewise, more significant associations might have been found if the study period had been longer.

\section{Conclusions}

Our results showed that temperature and seasonality were factors influencing influenza virus and RSV activity. In the whole population, both viral infections were associated with high IPD rates, while in children aged $<5$ years an association was found between adenovirus and RSV infections and IPD. Our results reinforce the idea that influenza vaccination may help prevent IPD.

\section{Availability of data and material}

The dataset supporting the conclusions of this article is included within the article.

\section{Additional file}

Additional file 1: Distribution of IPD, respiratory viruses and meteorological factors by month and year. Catalonia, 2006-2012. (XLS 46 kb)

\section{Abbreviations \\ Cl: confidence intervals; Idescat: Statistical Institute of Catalonia; IPD: invasive pneumococcal disease; IR: incidence rate.; IRR: incidence rate ratios; MRSC: Microbiological Reporting System of Catalonia; PCR: polymerase chain reaction; PCV13: 13-valent pneumococcal conjugate vaccine; PCV7: 7- valent pneumococcal conjugate vaccine; PPV23: 23-valent pneumococcal polysaccharide vaccine; RSV: respiratory syncytial virus.}

\section{Competing interests}

The authors declare that they have no competing interests.

\section{Authors' contributions}

PC made substantial contributions to the data collection process and to the conception, design, analysis, and interpretation of data. She drafted and revised the manuscript, gave the final approval of the version to be published, and is the corresponding author. SB conducted the statistical analysis. SB, Cl, SH, CMA, RP, MJ and $A D$ made contributions to the interpretation of the data, provided comments on the draft and have read and approved the final version. The other members of the Working Group contributed to data collection, interpretation of the results and editing the manuscript. All authors read and approved the final manuscript.

\section{Acknowledgements}

The authors thank the Working Group of the Microbiological Reporting System of Catalonia (MRSC) of the Public Health Agency of Catalonia. In addition to the authors in the Working Group of Invasive Pneumococcal Disease of Catalonia, the following are included: F Marco $(\mathrm{H}$. Clínic i Provincial de Barcelona); C Ardanuy, I Grau (H. Universitari de Bellvitge, Bellvitge); M Mico (H. Santa Creu i Sant Pau, Barcelona); A Gonzalez-Cuevas (H. General del Parc Sanitari Sant Joan de Déu, Barcelona); A Díaz (H. de Nens, Barcelona); G Codina, N Larrosa (H. Universitari Vall d'Hebron, Barcelona); M Sierra (H. de Barcelona, Barcelona); M Curriu (H. Sant Bernabe, Berga); C Gallés, A Puig (H. Sant Jaume, Calella); C Esteva, S Hernández-Bou (H. Universitari Sant Joan de Deu, Esplugues); P Gassiot (H. de Figueras, Figueras); M Martínez-Zurita ( $H$. Josep Trueta, Girona); C Martí ( $\mathrm{H}$. General Granollers, Granollers); M Morta ( $H$. Sant Joan de Deu, Manresa); G Sauca (H. de Mataró, Mataró); A Gassós (H. Sant Joan de Deu de Martorell, Martorell); E Sanfeliu (H. Sant Jaume, Olot); F Ballester (H. Sant Joan, Reus); M Olsina (H. General de Catalunya, Sant Cugat del Valles); X Raga (H. Sant Pau i Santa Tecla, Tarragona); F Gómez-Bertomeu (H. Joan XXIII, Tarragona); MO Pérez-Moreno ( $H$. Verge de la Cinta, Tortosa); A Vilamala $(H$. General de Vic, Vic); M Ribelles ( $H$. Universitari Arnau de Vilanova de Lleida, Lleida); J Gómez, V Plasencia (Laboratori de Referència Catalunya); D Fontanals (Corporació Sanitària-Institut Universitari Parc Taulí. UAB, Barcelona); MA Benitez; E Jou (Consorci Laboratori Intercomarcal Alt Penedès, Anoia i Garraf); M Giménez, MD Quesada (H. Universitari Germans Trias i Pujol, Badalona); JC de la Fuente (H. Comarcal Móra d'Ebre); A Calderon (H. Municipal de Badalona, Badalona); MJ Fusté (Clínica Terres de l'Ebre); L Vega (H. Universitari Quiron-Dexeus, Barcelona); J Pérez-Jové, M Simó (Catlab-Centre Analítiques Terrassa, AlE). 


\section{Funding}

This study was partially funded by the Catalan Agency for the Management of Grants for University Research (AGAUR Grant number 2014/SGR 1403) and by SplDnet (Assessing the impact of vaccination with the conjugate vaccines on the epidemiology of invasive pneumococcal disease in Europe), a programme funded by the European Centre for Disease Prevention and Control (ECDC/2012/038).

\section{Author details}

${ }^{1}$ Agència de Salut Pública de Catalunya. Generalitat de Catalunya, Roc Boronat 81-95, 08005 Barcelona, Spain. ${ }^{2}$ Hospital Universitario Sant Joan de Deu, Po Sant Joan de Deu 2, 08950 Esplugues, Barcelona, Spain. ${ }^{3}$ Hospital Universitario Bellvitge, Feixa Llarga s/n, 08907 L'Hospitalet, Barcelona, Spain. ${ }^{4}$ Universidad de Barcelona, Casanova 143, 08036 Barcelona, Spain. ${ }^{5}$ CIBER de Epidemiología y Salud Pública (CIBERESP), Instituto de Salud Carlos III, Monforte de Lemos, 3-5, 28029 Madrid, Spain.

Received: 31 December 2015 Accepted: 29 April 2016

Published online: 13 May 2016

\section{References}

1. Domínguez A, Salleras L, Cardeñosa N, Ciruela P, Carmona G, Martínez A, et al. The epidemiology of invasive Streptococcus pneumoniae disease in Catalonia (Spain). A hospital-based study. Vaccine. 2002;20:2989-94.

2. Kim PE, Musher DM, Glezen WP, Rodriguez-Barradas MC, Nahm WK, Wright CE. Association of invasive pneumococcal disease with season, atmospheric conditions, air pollution, and the isolation of respiratory viruses. Clin Infect Dis. 1996:22:100-6.

3. Jarstrand C, Tunevall G. The influence of bacterial superinfection on the clinical course of influenza: studies from the influenza epidemics in Stockholm during the winters 1969-70 and 1971-72. Scand J Infect Dis. 1975;7:243-7.

4. O'Brien $\mathrm{KL}$, Walters Ml, Sellman J, Quinlisk P, Regnery H, Schwartz B, et al. Severe pneumococcal pneumonia in previously healthy children: the role of preceding influenza infection. Clin Infect Dis. 2000;30:784-9.

5. Izquierdo C, Ciruela P, Hernández S, Domínguez A. Generalitat de Catalunya. Agència de Salut Pública de Catalunya. Vigilància epidemiològica de la infecció respiratòria aguda a Catalunya. Sistema de notificació microbiològica de Catalunya. Anys 2005-2008. Butlletí Epidemiològic de Catalunya 2011:XXXII:3842. Available at: http://scientiasalut.gencat.cat/bitstream/handle/11351/851/ BEC_abril_2011.pdf?sequence=1. Accessed 18 Jun 2014.

6. Muñoz-Almagro C, Bautista C, Arias MT, Boixeda R, Del Amo E, Borrás C, et al. High prevalence of genetically-determined mannose binding lectin deficiency in young children with invasive pneumococcal disease. Clin Microbiol Infect. 2014;20:0745-52

7. Ciruela P, Soldevila N, Hernández S, Selva L, de Sevilla MF, García-García JJ, et al. Risk factors for invasive pneumococcal disease in a community with a high proportion of non vaccine serotypes. Vaccine. 2013;31:960-66.

8. Murdoch DR, Jennings LC. Association of respiratory virus activity and environmental factors with the incidence of invasive pneumococcal disease. J Infection. 2009;58:37-46.

9. Avadhanula V, Rodriguez CA, Devincenzo JP, Wang Y, Webby RJ, Ulett GC, et al. Respiratory viruses augment the adhesion of bacterial pathogens to respiratory epithelium in a viral species- and cell type-dependent manner. J Virol. 2006;80:1629-36.

10. Pittet LA, Hall-Stoodley L, Rutkowski MR, Harmsen AG. Influenza virus infection decreases tracheal mucociliary velocity and clearance of Streptococcus pneumoniae. Am J Respir Cell Mol Biol. 2010;42:450-60.

11. Fainstein V, Musher DM, Cate TR. Bacterial adherence to pharyngeal cells during viral infection. J Infect Dis. 1980;141:172-6.

12. Musher DM. How contagious are common respiratory infections? N Engl J Med. 2003;348:1256-66.

13. Ciruela P, Martínez A, Izquierdo C, Hernández S, Broner S, Muñoz-Almagro C, et al. Epidemiology of vaccine-preventable invasive diseases in Catalonia in the era of conjugate vaccines. Hum Vaccin Immunother. 2013;9:681-91.

14. Generalitat de Catalunya. Departament de Salut. Manual de vacunacions. Col leció: Quaderns de salut pública, 14. 4th ed. Direcció General de Salut Pública. Barcelona 2006 Available at: http://canalsalut.gencat.cat/web/.content/home_ canal_salut/ciutadania/la_salut_de_la_a_a_la_z/v/vacunacions/documents/ manualvacunes06.pdf. Accessed 18 Jun 2014.
15. Domínguez A, Izquierdo C, Salleras L, Ruiz L, Sousa D, Bayas JM, et al. Effectiveness of the pneumococcal polysaccharide vaccine in preventing pneumonia in the elderly. Eur Respir J. 2010;36:608-14.

16. Moraga-Llop F, Garcia-Garcia JJ, Diaz-Conradi A, Ciruela P, Martínez J, González $S$, et al. Vaccine failure in patients properly vaccinated with 13-valent pneumococcal conjugate vaccine in Catalonia, a region with low vaccination coverage. Pediatr Infect Dis J. 2016;35:460-3.

17. Ampofo K, Bender J, Sheng X, Korgenski K, Daly J, Pavia AT, et al. Seasonal invasive pneumococcal disease in children: role of preceding respiratory viral infection. Pediatrics. 2008;122:229-37.

18. Talbot TR, Poehling KA, Hartert TV, Arbogast PG, Halasa NB, Edwards KM, et al. Seasonality of invasive pneumococcal disease: temporal relation to documented influenza and respiratory syncytial viral circulation. Am J Med. 2005;118:285-91.

19. Jansen AG, Sanders EA, Van Der Ende A, Van Loon AM, Hoes AW, Hak E. Invasive pneumococcal and meningococcal disease: association with influenza virus and respiratory syncytial virus activity? Epidemiol Infect. 2008;136:1448-54.

20. Nicoli EJ, Trotter CL, Turner KM, Colijn C, Waight P, Miller E. Influenza and RSV make a modest contribution to invasive pneumococcal disease incidence in the UK. J Infect. 2013;66:512-20.

21. The Statistical Institute of Catalonia. Available at: http://www.idescat.cat. Accessed 18 Jun 2014.

22. World Health Organization. Protocol for the assessment of national communicable disease surveillance and response systems. World Health Organization. 2001. WHO/CDS/IRS/2001.2. Annex 1.0.

23. Ciruela $P$, Hernández $S$, Tomàs $M$, Jané $M$. Generalitat de Catalunya. Agència de Salut Pública de Catalunya. Anàlisi dels microorganismes declarats al sistema de notificació microbiològica de Catalunya durant els anys 20112012. Butlletí Epidemiològic de Catalunya 2014;XXXV:148-56. Available at: http://canalsalut.gencat.cat/web/.content/home_canal_salut/professionals/ recursos/butlletins_de_salut/promocio_i_proteccio_de_la_salut/bec_ butlleti_epidemiologic_de_catalunya/2014/bec_novembre_2014.pdf. Accessed 18 Jun 2015

24. National Statistics Institute. Available at: http://www.ine.es. Accessed 18 Jun 2014.

25. Meteorological Service of Catalonia. Available at: http://www.meteo.cat. Accessed 18 Jun 2014.

26. Watson M, Gilmour R, Menzies R, Ferson M, Mclntyre P. The association of respiratory viruses, temperature, and other climatic parameters with the incidence of invasive pneumococcal disease in Sydney, Australia. Clin Infect Dis. 2006;42:211-5.

27. Dowell SF, Whitney CG, Wright C, Rose Jr CE, Schuchat A. Seasonal patterns of invasive pneumococcal disease. Emerg Infect Dis. 2003;9:573-9.

28. Peltola V, Heikkinen T, Ruuskanen O, Jartti T, Hovi T, Kilpi T, et al. Temporal association between rhinovirus circulation in the community and invasive pneumococcal disease in children. Pediatr Infect Dis J. 2011;30:456-61.

\section{Submit your next manuscript to BioMed Central and we will help you at every step:}

- We accept pre-submission inquiries

- Our selector tool helps you to find the most relevant journal

- We provide round the clock customer support

- Convenient online submission

- Thorough peer review

- Inclusion in PubMed and all major indexing services

- Maximum visibility for your research

Submit your manuscript at www.biomedcentral.com/submit 